\title{
PROFESSIONALISME MET VERWYSING NA DIE POSISIE VAN BEDRYFSIELKUNDE EN DIE BEDRYFSIELKUNDIGE IN SUID-AFRIKA
}

\section{A. VAN DER MERWE}

AFDELING MANNEKRAG

SUID-AFRIKAANSE SPOORWEË EN HAWENS

\begin{abstract}
Industrial Psychology, as a relatively new but fast-growing science is evaluated on the basis of six criteria for a profession. Results in this regard indicate that for a number of years the discipline has been in the process of evolving into a full-fledged profession and that this process has made advancement along the professional continuum. Further investigations regarding the professional training, the statutory organising of Industrial Psychology as well as a professional code and association for Industrial Psychology are needed in order to fully consolidate the professional status of the discipline.
\end{abstract}

Die besondere kenmerke van die Bedryfsielkunde, onder andere, die verwantskap daarvan met verskeie ander wetenskapsdissiplines (byvoorbeeld geestes-, ekonomiese- en sosiale wetenskappe), plaas dit in 'n unieke posisie om feitlik alle fasette van menslike gedrag in die bedryf en beroepslewe op 'n wetenskaplike wyse te bestudeer.

Hierbenewens beskik die Bedryfsielkunde ook oor tegnieke en middels (byvoorbeeld toetse, opleidingstegnieke) om die aanpasbaarheid en produktiwiteit van die mens as arbeidseenheid te optimaliseer. Hieruit is dit duidelik dat die vakgebied op die arbeidsekonomiese terrein sy toepassingswaarde vind en sy praktiese bydrae maak of behoort te maak.

Hierdie unieke posisie van die Bedryfsielkunde vereis noodwendig van die beoefenaar daarvan om oor 'n breë front op te tree en sodoende met verskeie ander professies te skakel. Dit is om hierdie rede dat die bedryfsielkundige opsigself ' $n$ sekere standaard van bevoegdheid moet handhaaf ten einde 'n doeltreffende diens te kan lewer. Dan alleen sal die vakgebied ook as professie die nodige gesagsposisie en outonomie, noodsaaklik vir die voortbestaan daarvan, kan handhaaf. Die aard van opleiding wat die bedryfsielkundige ontvang, bepaal grootliks (maar nie uitsluitlik nie) sy standaard van bevoegdheid of 
kundigheid. Hieroor word gereeld en omvattend, veral deur bedryfsielkundiges in die akademiese wêreld, gepubliseer. Daar word in hierdie verband in besonder verwys na artikels wat deur Augustyn, De Villiers, Raubenheimer en Van Biljon (1978), Botha (1977), Kamfer (1977), Langenhoven (1977), Raubenheimer, Calitz, De Villiers en Augustyn (1976), Schoeman (1978) en Vlok (1977) oor die opleiding van bedryfsielkundiges aan verskeie universiteite asook die opleiding van bedryfsielkundiges in Suid-Afrika in die algemeen, in hierdie tydskrif gepubliseer is.

Ofskoon daar in hierdie artikels en ook in ander soortgelyke artikels 'n duidelike aanduiding verkry kan word van die omvang en aard van die opleiding wat bedryfsielkundiges in Suid-Afrika geniet, word die wetenskaplike aard en professionele waarde van die vakgebied steeds bevraagteken. Dit is moontlik die geval omrede Bedryfsielkunde as betreklike jong vakgebied, anders as meeste ander professies, binne 'n kort tydsbestek 'n sterk invloed op die arbeidsekonomiese terrein uitgeoefen het.

Om gevolglik die Bedryfsielkunde as wetenskaplike professie in die algemeen en voortvloeiend hieruit die posisie van die bedryfsielkundige in Suid-Afrika in die besonder in hierdie verband, omvattend te evalueer, sal daar na 'n maatstaf (kriterium) vir professionalisme gesoek moet word om te kan bepaal hoe staan Bedryfsielkunde met betrekking tot die "professionele model".

\section{PROFESSIONALISME}

\section{Algemeen}

'n Professie (verwys onder andere Elliott, 1972; Hornby, Gatenby \& Wakefield, 1963; Kerr \& Von Glinow, 1977; Vollmer \& Mills, 1966) impliseer 'n beroep of 'n werk met bepaalde eiesoortige kenmerke of kan ook na aanleiding van Vollmer en Mills (1966) as 'n besondere vorm van beroepsorganisasie beskryf word. Professionalisme is weer 'n ideologie waarna beroepsgroepe strewe om sodoende professionele status te verkry (Vollmer \& Mills, 1966). In aansluiting hierby beskryf Elliott (1972) professionalisme as 'n sosiale proses of een van die metodes waardeur kennis wat aan die gemeenskap beskikbaar is, ontwikkel en gebruik word in die uitvoering van gespesialiseerde take. Professionalisme op sy beurt geskied deur die proses van professionalisasie. Professionalisasie verwys na die proses waardeur daar by 'n besondere beroep mettertyd standaarde en norme ontwikkel wat eiesoortig aan die professies is (Goode in Vollmer \& Mills, 1966; Elliott, 1972). 
Professionalisasie veroorsaak sodoende 'n spesiale vorm van beroepsorganisasie in die sosiale gemeenskap, deurdat dit die formele struktuur en doelstellings van die besondere beroep verander (Elliott, 1972). Goode (Vollmer \& Mills, 1966) soos aangehaal deur Elliott (1972), verwys hierna as "communities within a community" as synde verskeie professies of professionele groepe met hul eiesoortige norme binne die groter gemeenskap te wees.

Die strewe van beroepe deur professionalisasie na volwaardige professionele status geskied volgens Theodore (1971), deur die skepping van, wat vandag bekend staan as professionele verenigings.

Afgesien van die betekenis van die konsep professie waarna hierbo verwys is, word dit ook as verklaring vir die woord "profession", beskryf as 'n "statement or declaration of belief" (Hornby, et al., 1963, p. 773). Argyris en Schön (1975, p. 146) skryf in hierdie verband: "Each of the professions seems to have been bound up in its origin with a faith professed that is with values to be achieved through the activities of the profession".

As voorbeelde noem Argyris en Schön die medikus wat onderneem het om gesondheid te bevorder, die regsgelêerde wat onderneem het om regverdigheid te bevorder en die teoloog wat onderneem het om verlossing te verkondig. Hierdie tema vorm 'n integrale komponent van die ideologie van die professies, naamlik die bevordering van die welvaart van die gemeenskap (Argyris \& Schön, 1975; Duckat, 1970; Elliott, 1972; Goode in Vollmer \& Mills, 1966; MacFarlane, 1952).

In weerwil van die uniekheid van professies wat in die voorafgaande op 'n oorsigtelike wyse beklemtoon is, word die begrip steeds hedendaags wyd en op 'n ontoepaslike wyse ten opsigte van 'n verskeidenheid van beroepe gebruik (Elliott, 1972; Kerr \& Von Glinow, 1977). Volgens Friedson - soos deur Kerr en Von Glinow (1977) aangehaal, is dit een van die redes waarom daar in die literatuur soveel variasies in definisies vir die professiekonsep bestaan. Friedson (1971, pp. 3-4), skryf in hierdie verband: "Virtually all self-conscious occupational groups apply it to themselves at one time or another, either to flatter themselves or to try to persuade others of their importance. Occupations to which the word has been applied are thus so varied as to have nothing in common, save a hunger for prestige. Since people do not agree which occupations 'are' professions ... their definitions vary with the occupations they include or else are alike on such an abstract level as to be virtually inapplicable to the task of distinguishing real occupations". 
Elliott (1972, p. 3), beweer voorts dat die byvoeglike naamwoord "professional" selfs nog in ' $n$ groter mate as die selfstandige naamwoord professie misbruik word en noem as voorbeeld die feit dat dit dikwels as teenoorgestelde van amateur en ook as teenoorgestelde van knoeiwerk gebruik word. Dit is twee begrippe wat volgens Elliott geensins sinoniem is nie. Ander skrywers (byvoorbeeld Carr-Saunders in Vollmer \& Mills, 1966), is egter nog meer krities in hierdie verband. Nadat die begrip "professional fireman" in die "Fire Brigades Pensions Act" van 1925 in Brittanje vir brandweermanne wat permanent vuurbestryding beoefen in gebruik geneem is, het Carr-Saunders as volg daarop gereageer: "Without in any way wishing to disparage the valuable services of whole time firemen, I suggest that to describe their functions as professional is to misuse a word to which a restricted and definite meaning is commonly attached" (Vollmer \& Mills, 1966, p. 4).

Ten einde groter duidelikheid oor die spesifieke afgebakende betekenis van 'n professie en professionalisme waarna Carr-Saunders verwys te verkry, sal die besondere aard en kenmerke van professies vervolgens behandel word.

\section{Besondere aard en kenmerke}

\section{Proses van professionalisasie}

Die proses van professionalisasie word gekenmerk deur 'n reeks stadia wat veranderinge in die formele struktuur van 'n beroep teweegbring namate hierdie beroep vir professionele status aspireer (Caroll, 1970; Elliott, 1972; Theodore, 1971). Dit is 'n dinamiese proses waardeur 'n beroep in die rigting van 'n professie beweeg (Vollmer \& Mills, 1966). Die konsep plaas voorts ook beroepe op 'n kontinuum, na gelang van sekere kriteria, met die nieprofessies aan die een kant (of pool) en die hoogs geïnstitusionaliseerde professies aan die ander kant (Vollmer \& Mills, 1966; Theodore, 1971). Hierdie vorm van professionele kategorisering veronderstel 'n model van die "ideale" professie en die ander beroepe word na gelang van hul ooreenkomste en verskille met die "ideale" professie op die professionele kontinuum of skaal geplaas (Kerr \& Von Glinow, 1977; Vollmer \& Mills, 1966). Professionalisasie kan 'n beroep dus in 'n meerdere of mindere mate beïnvloed (Vollmer \& Mills, 1966).

Carr-Saunders, Greenwood en Caplow (Vollmer \& Mills, 1966), Theodore (1971) en Elliott (1972) na aanleiding van Wilensky identifiseer die volgende stappe in die proses van professionalisasie oftewel beroepsprofessionalisasie naamlik: (a) 'n Liggaam van kennis word opgebou en gegrond op 'n sistematiese teorie en wat verkry kan word deur intellektuele studie en langdurige gespesialiseerde opleiding; (b) 'n professionele vereniging wat die standaarde 
en norms van die professie bepaal, ontstaan vervolgens. Hierdie professionele vereniging beywer hom gewoonlik vir (c) die daarstelling van spesifieke toelatings- en opleidingsvereistes en prosedures wat nagekom moet word alvorens professionele werk verrig kan word; (d) vervolgens sal die beroepsprofessie agiteer vir publieke erkenning en wetlike ondersteuning wat, indien dit verkry word, wetlike beheer oor professionele opleiding en professionele praktyk tot gevolg het. Vir die nodige wetlike beheer word dit gewoonlik van die beoefenaar van die professie vereis om 'n lisensie te bekom of te registreer by 'n wetlik beheerde instansie. (e) Laastens sal 'n etiese kode vir die regulering van professionele gedrag en verhoudings met kliënte en kollegas geskep word. Die professionele vereniging speel gewoonlik 'n prominente rol in die daarstelling van 'n etiese kode.

Al die skrywers hierbo aangehaal, stem egter nie ooreen wat die volgorde van die stadia in die professionalisasieproses betref nie. Caplow byvoorbeeld, sien die ontstaan van 'n professionele vereniging as die eerste stadium (Vollmer \& Mills, 1966). Al die stadia word ook nie deur al die skrywers geïdentifiseer nie, maar oorvleueling tussen skrywers het dit moontlik gemaak om die verskeie sienswyses tot bogemelde vyf stadia te reduseer. Hierdie stadia sou ook as die eerste vyf kriteria vir professionalisme gesien word. Hierdie vyf kriteria word dikwels ook met behulp van ander begrippe in die literatuur geïdentifiseer. Greenwood byvoorbeeld, sien die vorming van professionele verenigings tesame met die professionele opleidingsinstansies as die daarstelling van 'n professionele kultuur (McGehee, 1964; Vollmer \& Mills, 1966). Flexner soos aangehaal deur Carroll (1970) en Peterson (1976) vat kriteria (b), (c) en (d) hierbo saam en noem dit professionele organisasie. Flexner onderskei egter ook nog ander kriteria waaraan 'n professie gewoonlik voldoen soos: die doelstellings van 'n professie is prakties in die sin dat die liggaam van kennis gebruik word om sosiale of menslike probleme op te los; 'n professie het tegnieke of vaardighede wat aangelêer kan word en wat as meganismes dien waardeur kennis toegepas kan word om probleme op te los of waardeur die doelstellings van die professie bereik kan word; die aanleer en gebruik van hierdie tegnieke en vaardighede vereis intellektuele prosesse en tesame hiermee 'n groot persoonlike verantwoordelikheid in die oordeel wat aan die dag gelê moet word deur die beoefenaar van die professie. Dieselfde gedagtes word deur Elliott (1972, p. 94) geopper. Flexner noem voorts dat die doelstellings van 'n professie hoofsaaklik altruïsties is eerder as gemik op die bevordering van eiebelang. Implisiet ingeweef in hierdie altruïstiese benadering is 'n etiese gedragskode (Peterson, 1976). Verwys ook in hierdie verband die aspek van diensoriëntasie in Elliott (1972, p. 94). 
Schein soos aangehaal deur Boshoff en Hamblin (1976, p. 20) sien egter die hoofdoelstelling van professionalisme as die verkryging van outonomie. Dit impliseer in Schein se eie woorde: "knowing better what is good for the client than anyone else because of extended technical education and training; subjecting one's decisions only to the review of colleagues and setting all one's standards pertaining to jurisdiction of the profession and entry into it through peer group association". Greenwood soos aangehaal deur McGehee(1964, p. 801) verwys na outonomie as professionele gesag en noem ook pertinent gespesialiseerde kennis opgedoen deur wetenskaplike opvoeding en opleiding as die oorsprong daarvan.

Dit dien ook gemeld te word dat Carr-Saunders (Vollmer \& Mills, 1966) professionele diens of advies teen 'n vasgestelde fooi of salaris as 'n verdere uitstaande kenmerk van 'n professie beskou. Carr-Saunders noem in hierdie verband dat die "ouer" professies wat meestal deur ' $n$ private praktyk beoefen is, gewoonlik op 'n fooi as vergoeding aangewese was, terwyl die beoefenaars van die jonger professies wat dikwels in 'n handelsonderneming bedryf word, deur middel van 'n salaris vergoed word. Al wat egter in hierdie verband van belang is, is dat die vergoeding direk en vasgestel moet wees (Carr-Saunders in Vollmer \& Mills, 1966, p.4; Freidson, 1971, p. 71).

\section{Samevatting en bespreking}

Die voorafgaande toon 'n klaarblyklike oorvleueling in sekere konsepte aan. Ten einde hierdie toedrag van sake op te klaar, sal daar gepoog word om 'n samevattende lys van kriteria op te stel wat as maatstaf vir 'n "ideale" professie kan dien. Hierdie kriteria sal as strukturele kenmerke (dit wil sê te make met die struktuur van die professie) geëien word, aangesien hierdie tipe kenmerke meer objektief ontleed en as 'n objektiewe maatstaf vir toepassing/ vergelyking gebruik kan word. Waar moontlik sal individu-gebaseerde kenmerke (dit wil sê te make met die persoonlike kenmerke van die beoefenaar van die professie) egter as uitvloeisels van gemelde strukturele kenmerke geïdentifiseer word.

- $\quad$ 'n Professie vereis eerstens 'n liggaam van kennis gebaseer op 'n sistematiese teorie.

Ofskoon daar verskeie wyses bestaan waarop kennis verkry kan word, is dit in besonder kennis verkry deur die wetenskaplike metode wat vir ons in hierdie verband van belang is (Kerlinger, 1973). Die wetenskaplike metode kan gebruik word om objektiewe wetenskaplike teorieë daar te stel wat aan die voornemende professionalis 'n objektiewe wetenskaplike verwysingsraamwerk bied waarin sy tegnieke en praktiese kennis gefundeer is. Hierdie kennis voorsien die gespesialiseerde kundigheid aan die 
beoefenaar van die professie teenoor die van die nie-professie. Volgens Greenwood (Vollmer \& Mills, 1966) is dit egter nie die kundigheid wat as kriterium van onderskeiding tussen die twee groepe dien nie, maar juis die "liggaam van teorie" waaruit dit voortvloei. Kundigheid word ook by die nie-professies gevind, maar die "liggaam van teorie is gewoonlik afwesig. Greenwood skryf verder hieroor as volg: "The importance of theory precipitates a form of activity normally not encountered in a nonprofessional ,occupation, viz., theory construction via systematic research. To generate valid theory that will provide a solid base for professional techniques requires the application of scientific method to the service-related problems of the profession". (Vollmer \& Mills, 1966, p. 12).

Ter aansluiting by Flexner (1915) hierbo is dit uit die voorafgaande duidelik dat voorbereiding vir 'n professie intellektuele sowel as praktiese prosesse vereis om onderskeidelik die teorieë en die vaardighede/tegnieke (gebaseer op hierdie teorieë) baas te raak ten einde later die professie te beoefen (Greenwood in Vollmer \& Mills, 1966).

Die liggaam van sistematiese kennis en vaardighede/tegnieke wat die professionalis aanleer maak van hom ' $\mathrm{n}$ outoriteit op sy gebied en gee hom tesame met sy kollegas ' $\mathrm{n}$ monopolie in 'n sekere beroeps- en arbeidsterrein (Beach, 1970; Chapman, 1963). Die gesag (byvoorbeeld die reg om aan kliënte voor te skryf) en outonomie (selfbeskikkingsreg) wat verder hieruit voortvloei word gesien as afhanklike veranderlikes van die onafhanklike veranderlike liggaam van kennis. Al sou onder andere Freidson (1971) outonomie as die mees strategiese en waardevolste kenmerk van 'n professie beskou, word dit nie as 'n kriterium op sigself beskou nie, maar wel as 'n kenmerk voortvloeiend uit die kriterium "liggaam van kennis" en dit wat daarmee saamgaan. Dieselfde beskouing kan ten opsigte van kundigheid, outoriteit, gesag en monopolie in 'n beroepsterrein gehandhaaf word.

- $\quad$ 'n Tweede kriterium waaraan 'n professie moet voldoen is uitgebreide gespesialiseerde opleiding om die liggaam van kennis en vaardighede by die beoefenaar van 'n professie te kweek en wat gewoonlik as bevoegdheidstandaard vir toelating tot die professie dien.

Hierdie kriterium kan ook as 'n onafhanklike veranderlike beskou word aangesien dit bepaal watter prosesse en prosedures 'n voornemende beoefenaar van 'n professie moet 
deurloop alvorens hy die liggaam van kennis en vaardighede sowel as toelating tot die professie kan verkry.

Hierdie uitgebreide gespesialiseerde opleiding is gewoonlik langdurig van aard en bestaan uit twee komponente, naamlik opleiding in teorie en opleiding in die toepassing van teoretiese kennis, insluitend die aanleer van praktiese tegnieke en vaardighede. Opleiding in teorie word die beste deur formele opleiding in 'n akademiese instelling soos byvoorbeeld 'n universiteit of professionele skool verkry (Greenwood in Vollmer \& Mills, 1966; Theodore, 1971). Die voornemende professionalis sal as praktiese deel van sy professionele opleiding ondervinding opdoen in die "veld" waar hy later professionele diens moet gaan lewer (Argyris \& Schön, 1975). Verwys in hierdie verband na die internskappe wat deur medici, sielkundiges, ensovoorts gevolg word en die praktiese opleiding wat leerling-ingenieurs en beoefenaars van die regsprofessie moet deurloop alvorens toelating tot die volwaardige professie en professionele praktyk verkry word (Anoniem, 1941; Uhrbrock,1955; Wilson, 1956). Hierdie twee komponente van professionele opleiding kan afsonderlik of gelyktydig deurloop word (Mackinney, 1968).

Aangesien hierdie opleiding gewoonlik as bevoegdheidstandaard vir toelating tot die professie dien, het dit onder andere die volgende definitiewe oogmerke met betrekking tot die toekomstige professionalis, naamlik die aankweek van die vermoë om krities en analities te dink, asook die vermoë om te sintetiseer en te veralgemeen; die aankweek van houdings wat hom toepaslik sal laat dink en optree (byvoorbeeld die verwydering van vooroordele); die aankweek van die vermoë om sinvolle inter-professionele verhoudinge met kollegas te ontwikkel en te handhaaf en die ontwikkeling van 'n diensoriëntasie teenoor die sosiale gemeenskap (dit wil sê 'n sosiale bewustheid en 'n sosiale gewete) (Korman, 1974; Towle, 1954).

Wanneer die voornemende professionalis die nodige opleiding deurgegaan het, is hy gereed vir toelating tot die professie. Dit word gewoonlik verkry deur registrasie by 'n beroepsraad of professionele vereniging, of die verkryging van ' $n$ lisensie om te praktiseer by sodanige raad of vereniging (Freidson, 1971; Hattingh, 1966; Towle, 1954). Hierdie aspek bring ons by die volgende kriterium vir 'n professie, naamlik:

- $\quad$ gemeenskaps- en wetlike goedkeuring en ondersteuning. Formele gemeenskapsgoedkeuring van 'n professie word verkry deur wetgewing wat tegelykertyd wetlike beheer 
oor professionele opleiding en toelating tot die professie meebring (Greenwood en Caplow in Vollmer \& Mills, 1966). Deur hierdie stelsel van wetlike beheer/beskerming word daar outonomie aan 'n professie op sy beroepsterrein gegee te wete die eksklusiewe reg om te bepaal wie wettiglik professionele funksies mag verrig en hoe dit verrig behoort te word (Freidson, 1971).

Hierdie regulering van 'n professionele diens of funksie vind deur 'n akkrediteringsproses plaas wat tot gevolg het dat professionele opleidingsinstansies beheer word met betrekking tot onder andere hul leerplaninhoud, kwaliteit van instruksie/opvoeding, ensovoorts. 'n Soortgelyke vorm van wetlike beheer/ondersteuning word nie by die nieprofessies aangetref nie (Greenwood in Vollmer \& Mills, 1966).

Bo en behalwe die gesag, outonomie en beskerming wat wetlike beheer aan die professie bied, bly die primêre doel egter steeds om die publiek teen onbevoegde persone en onetiese praktyke te beskerm (Elliott, 1972; Wolfle, 1950).

- $\quad$ Dit is reeds duidelik dat 'n professie nie sonder 'n professionele vereniging kan funksioneer nie. Dit vorm die vierde kriterium van 'n professie (Carr-Saunders, Greenwood en Caplow in Vollmer \& Mills, 1966; Flexner soos aangehaal deur Carroll, 1970; Theodore, 1971; Elliot, 1972). 'n Professionele vereniging ontstaan wanneer lede van ' $n$ professie bewus raak van hul gemeenskaplike kenmerke en oogmerke (Greenwood in Vollmer \& Mills, 1966). Mettertyd behartig die professionele vereniging dan gewoonlik die organisasie van die professie in die sin dat dit die funksies en doelstellings van die professie definieer en norms en standaarde binne die professie bepaal. Dit vorm volgens Greenwood sodoende een van die formele groepe van die sogenaamde professionele kultuur. Die ander groepe word deur opvoedings- en navorsingsinstansies en instansies waar die professie beoefen word soos byvoorbeeld hospitale, ingenieursfirmas, klinieke, ens. verteenwoordig.

Voorts dien die vereniging as offisiële mondstuk van die professie daar dit na die belange van die lede (byvoorbeeld die vergoeding van lede) omsien (Carr-Saunders en Greenwood in Vollmer \& Mills, 1966; Brayfield, 1968; Freidson, 1971; Willensky soos aangehaal deur Elliott, 1972).

Die professionele vereniging speel 'n groot rol in die bepaling van opleiding en seleksieprosedures binne die professie en dien ook as bemiddelaar waardeur die professie vir 
publieke erkenning en wetlike ondersteuning agiteer en soms verkry (Carr-Saunders in Vollmer \& Mills, 1966; Wilensky soos aangehaal deur Elliot, 1972).

Ofskoon dit dikwels gebeur dat meer as een professionele vereniging binne 'n professie bestaan is die neiging eerder in die rigting van een dominante vereniging, hetsy deur amalgamasie of eliminering (Carr-Saunders in Vollmer \& Mills, 1966). Voorts dien gemeld te word dat wanneer 'n professie in spesialiteite of sub-spesialiteite verdeel, daar segmentasie in die professionele vereniging plaasvind. Dit wil sê daar bestaan dan 'n dominante vereniging met sub-verenigings geaffilieer aan hierdie dominante vereniging (Bucher en Strauss in Vollmer \& Mills, 1966).

Deur die professionele vereniging met sy besondere vereistes neem beoefenaars van die professie bepaalde norms en waardes aan. Dit op sigself skep 'n vorm van sosiale kontrole oor die professionele praktyk (veral die individuele praktisyn) wat belangrik is vir die beskerming van die gemeenskap teen uitbuiting (Elliott, 1972). Dit wil sê die individuele professionalis kan nie na gelang van eiebelang optree nie. Dit bring ons by die volgende kriterium van 'n professie, naamlik:

- $\quad$ die lewering van 'n altruïstiese diens gekontroleer deur 'n professionele/etiese gedragskode. Hierdie etiese gedragskode is 'n stel reëls en/of beginsels wat normaalweg deur die professionele vereniging opgestel word en wat deur lede van die professie nagekom moet word ten einde enersyds die "goeie naam" van die professie te beskerm en andersyds terselfdertyd 'n onbaatsugtige diens aan die gemeenskap te lewer (CarrSaunders in Vollmer \& Mills, 1966; Durkheim, 1957; Flexner in Carroll, 1970).

Etiese kodes word by alle beroepe aangetref (ook by die nie-professies), maar die professionele kode word gekenmerk deur 'n meer bepaalde/uitdruklike, sistematiese en bindende formaat en dit het beslis meer altruïstiese botone en dit is meer publieke diensgeoriënteerd (Greenwood in Vollmer \& Mills, 1966). Voorts word daar gewoonlik deur wetgewing sorg gedra dat lede van 'n besondere professie hulself by 'n sekere standaard van optrede/dienslewering hou.

In die toepassing van sy gespesialiseerde kennis kan die beoefenaar van 'n professie vir hom 'n inkomste verdien waaruit hy 'n bestaan kan maak. Dit bring ons by die sesde kriterium van 'n professie naamlik:

- $\quad$ die lewering van 'n diens vir 'n direkte, vasgestelde fooi of salaris (Carr-Saunders in Vollmer \& Mills, 1966). 
Die professionalis onderskei hom van die amateur in die sin dat eersgenoemde sy professie beoefen (dienste lewer) teen 'n direkte vasgestelde fooi of salaris wat sy primêre bron van inkomste is, terwyl laasgenoemde 'n aktiwiteit beoefen weens 'n persoonlike voorliefde vir hierdie aktiwiteit (Carr-Saunders in Vollmer \& Mills, 1966; Hornby et al, 1963; en Schein in Boshoff en Hamblin, 1976).

Professionele vergoeding is vasgestel, dit wil sê die betaling is gewoonlik na gelang van die tydsduur van die professionele diens (byvoorbeeld R10 per uur of selfs R1 000 per maand), en dit is direk van aard, dit wil sê die vergoeding vir die professionele diens bevat geen indirekte komponent (byvoorbeeld byvoordele) nie (Anoniem, 1978; Bent, 1972; CarrSaunders in Vollmer \& Mills, 1966).

Ter verduideliking in hierdie verband, dien gemeld te word dat wanneer 'n professionalis in diens van 'n organisasie is, kan dit meebring dat hy moontlik 'n vorm van indirekte vergoeding ontvang (byvoorbeeld vakansiebonus). Dit kan egter nie as deel van sy professionele vergoeding beskou word nie, maar slegs as 'n universele byvoordeel omrede hy 'n persooneellid van gemelde organisasie is.

Die koste van professionele dienste (dit is die salaris of fooi betaalbaar) word gewoonlik bepaal na gelang van die waarde wat dit vir die kliënt (hetsy individu of organisasie) inhou, met ander woorde, die kliënt se bereidwilligheid om te betaal. Ander aspekte soos professionele kundigheid, professionele verantwoordelikheid en ook die uitgawe wat die professionalis moet aangaan ten einde die diens te kan lewer, word ook in berekening gebring by die vergoeding vir professionele dienste (Anoniem, 1978; Van der Merwe, 1979).

\section{DIE POSISIE VAN BEDRYFSIELKUNDE EN DIE BEDRYFSIELKUNDIGE IN SUID-AFRIKA}

Uit die voorafgaande literêre beskouing rakende 'n maatstaf vir professionalisme kan daar nou op 'n oorsigtelike wyse gekyk word hoe die posisie van Bedryfsielkunde en die bedryfsielkundige in Suid-Afrika in hierdie verband daar uitsien.

\section{Liggaam van kennis gebaseer op 'n sistematiese teorie}

Ofskoon Bedryfsielkunde in die algemene Sielkunde gefundeer is en ook skakeling met die sosiale en ekonomiese wetenskappe het, is die meeste skrywers dit eens dat dit vandag as onafhanklike toegepaste wetenskapsdissipline in eie reg beskou kan word (verwys onder 
andere Augustyn, 1977; Boshoff \& Hamblin, 1976; Dunnette, 1976; Raubenheimer,1974a; Swiegers, 1970).

Die toegepaste aard van die Bedryfsielkunde is geleë in die feit dat die praktiese nywerheids- en handelswêreld as "navorsingsveld" gebruik kan word om teorieë daar te stel wat aan die voornemende professionele bedryfsielkundige 'n nuttige liggaam van kennis bied waarmee hy sy professie kan beoefen (Orpen, 1972; Swiegers, 1970).

Orpen (1972, p. 12) skryf in hierdie verband as volg: "The significant contribution of the industrial psychologist lies in the fact that he brings with him, not so much a set of rules or specific facts, but rather a method of attacking problems, the so-called scientific method. This means that he relies on empirical observation, rather than subjective opinion, that he collects data as objectively as possible and that, whenever possible he carries out experiments to verify the hypotheses he forms from his observations".

Hierdie skepping van 'n wetenskaplike basis of teorie wat Orpen impliseer stel die bedryfsielkundige in staat om, soos reeds gemeld, sy professie te beoefen.

Daar dien voorts gemeld te word dat die aanleer van teorie sowel as kennis van die "werksveld" van die Bedryfsielkunde noodsaaklik is om die voornemende professionalis van die nodige liggaam van kennis te voorsien wat hom in staat sal stel om 'n optimum diens te lewer (Korman, 1974; MacKinney, 1968; Muchinsky, 1973) .

Muchinsky (1973) meld in hierdie verband dat die akademici en die nywerheidswêreld saam behoort te werk om professioneel bevoegde bedryfsielkundiges te produseer. Ofskoon gemelde skrywer met betrekking tot bedryfsielkundiges in die V.S.A. geskryf het, word die mening gehuldig dat hierdie feit net so van toepassing op die Suid-Afrikaanse situasie is.

\section{Uitgebreide gespesialiseerde opleiding}

Daar rus 'n verpligting op die bedryfsielkundige om 'n bydrae te maak ten einde op ' $n$ wetenskaplike wyse een van Suid-Afrika se grootste kostefaktore, naamlik arbeid, produktief te maak en produktief te hou (Augustyn, 1977; Langenhoven, 1969; Raubenheimer, 1974).

Die Wet op Geneeshere, Tandartse en Aanvullende Gesondheidsberoepe (no. 56 van 1974) soos gewysig (hierna genoem die Wet) wat onder andere die doel het om die term "sielkundige" (ook die bedryfsielkundige) te beskerm, hou verder in hierdie verband besondere implikasies vir die voornemende professionele bedryfsielkundige in, met besondere 
verwysing na die funksies wat van hom vereis sal word en die onderrig wat hiermee gepaard gaan.

Voorts stel die wye operasionele veld van die Bedryfsielkunde verskeie ander eise aan die beoefenaars van die professie en veral in die lig van die feit dat die bedryfsielkundige hoofsaaklik 'n werknemer in 'n groot organisasie is, is hy onderworpe aan die politieke druk inherent in so 'n situasie wat sy professionele integriteit soms tot die uiterste kan beproef (Boshoff \& Hamblin, 1976) .

Indien gemelde arbeidsekonomiese, wetlike en organisatoriese verpligtinge wat op die voornemende professionele bedryfsielkundige rus, in gedagte gehou word, is dit eweneens meer duidelik dat hy 'n besondere vorm van opleiding (professionele opleiding) moet deurloop om sy taak met die nodige effektiwiteit te kan uitvoer en sodoende sy dienslewering op 'n optimum peil te kan plaas.

Akademiese opleiding in Bedryfsielkunde in Suid-Afrika word aan vyftien van die sestien universiteite aangebied (Raubenheimer, et al., 1976) ofskoon daar slegs, sover vasgestel kan word, by agt van dié universiteite volwaardige afsonderlike departemente van Bedryfsielkunde bestaan.

'n Ontleding van bedryfsielkundige opleiding aan ses van bogemelde agt universiteite, het die volgende kenmerke na vore gebring:

- $\quad$ die vak word primêr beskou as 'n toegepaste wetenskap en skakeling met die praktyk word as ' $n$ hoë prioriteit beskou. Deur navorsingsprojekte poog Bedryfsielkunde departemente om wetenskaplike oplossings vir bedryfsprobleme te soek en deur konsultasie aan die bedryf, poog hulle om die toepassingsmoontlikhede van die wetenskap op die praktiese terrein uit te brei. Waar moontlik, word studente grootliks by gemelde projekte betrek ten einde hulle vir hul latere loopbaan in die praktyk voor te berei (Augustyn, et al., 1978; Botha, 1977; Kamfer, 1977; Langenhoven, 1977;

Schoeman, 1978).

- Ter aansluiting by die voorafgaande word die vakgebied, gedagtig aan die operasionele veld en funksies van die bedryfsielkundige oor 'n breë akademiese terrein aangebied. Op voorgraadse vlak word die vakgebied beskrywend gedek, maar gedagtig aan die praktiese aard daarvan, word blootstelling aan metodes en tegnieke van die Bedryfsielkunde ook reeds tydens hierdie fase beklemtoon. Op nagraadse vlak word 
dieselfde terreine gedek, maar wyer in omvang en in meer diepte asook met meer klem op navorsing.

Wat die vakinhoud as sulks betref, word daar deur die meeste departemente op die basiese Sielkunde as grondslag vir die Bedryfsielkunde klem gelê, ofskoon een of twee departemente dit minder sterk beklemtoon. Die meeste departemente, maar nie almal nie, bied ook al die hoofgebiede van die Bedryfsielkunde, naamlik organisasiesielkunde, personeelsielkunde, verbruikersielkunde, ergonomika, beroepsielkunde en psigometrika/ navorsingsmetodiek aan.

Daar dien voorts gemeld te word dat hierdie breedgerigte opleiding wat deur departemente aangebied word, voorts ook opleiding in die professionele hulpmiddels van die Bedryfsielkunde (onder andere onderhoudvoering en ander evaluasietegnieke, asook opleidingstegnieke en die toepassing en interpretasie van sielkundige toetse) insluit. Didaktiese metodes soos rolspelle, gevallestudies, praktiese werk en ander kleingroep opleidingsprosesse word ook deur die meeste departemente gebruik (Augustyn et al., 1978; Botha, 1977; Kamfer, 1977; Langenhoven, 1977; Schoeman, 1978; Vlok, 1977).

- $\quad$ Opleiding aan die onderskeie departemente van Bedryfsielkunde hou hoofsaaklik die volgende twee funksies/doelstellings van die Bedryfsielkunde in gedagte, naamlik die verbetering van die begrip van die mens in die werksituasie ter bevordering van werkstevredenheid en die verhoging van die kwaliteit van menslike inspanning (dit is produktiwiteit) (Augustyn et al., 1978; Langenhoven, 1977; Vlok, 1977).

- Die meeste departemente gee erkenning aan die Wet en poog dus om bedryfsielkundiges op te lei in die verwerwing van volle professionele status. Hiervolgens kan 'n individu as 'n sielkundige in die kategorie Bedryfsielkunde registreer nadat hy 'n Magister-graad in die Bedryfsielkunde verwerf het en minstens twaalf maande praktiese ondervinding (internskap) in sielkundige/bedryfsielkundige prosedures onder toesig van 'n geregistreerde sielkundige (kategorie Bedryfsielkunde)* opgedoen het.

In hierdie verband het enkele departemente reeds 'n "gerigte" magister (dit is gerig op die praktyk) en andere is besig om 'n gerigte magister te verwerk met die oog op die latere volg van 'n internskap en registrasie volgens die Wet (Augustyn, et al., 1978; Botha, 1977; Kamfer, 1977; Langenhoven, 1977; Schoeman, 1978; Vlok, 1977).

\footnotetext{
* Vanaf 1983 word twee registers deur die Beroepsraad gehou naamlik een vir sielkundiges en een vir bedryfsielkundiges.
} 
Die individu wat Bedryfsielkunde wil beoefen, kan slegs op beskerming onder die Wet aanspraak maak (dit wil sê toelating kry tot die professie) na die verwerwing van 'n meestersgraad en die deurloop van 'n bepaalde internskapsperiode.

Die internskap-opleidingsprogram wat deur die Mediese en Tandheelkundige Raad (Die Beroepsraad vir Sielkunde) opgestel is, dek die volgende areas van die vakgebied: Evaluering van personeel, opleiding en ontwikkeling van personeel, motivering van personeel, skakeling met kliënt-organisasies, sakeskole en ander instansies wat verband hou met Bedryfsielkunde asook opleiding in meer gespesialiseerde areas van die vakgebied soos ingenieursielkunde (ergonomika), werk- en metodestudie, bedryfsveiligheid en -ongelukke, voorligtingswerk met wanaangepaste personeel, advertensiewese, openbare betrekkinge ens. Met hierdie huidige opleidingsprogram as basis, stel organisasies tans hul eie curricula op wat op hul spesifieke behoeftes en fasiliteite gebaseer is en rig hul vertoë in hierdie verband aan die Mediese en Tandheelkundige Raad (Die Beroepsraad vir Sielkunde) vir die nodige goedkeuring en latere toepassing.

\section{Lisensiëring of registrasie - Formele gemeenskapsgoedkeuring}

Ofskoon Kliniese sielkundiges gedurende die sestigerjare reeds op 'n vrywillige grondslag by die Suid-Afrikaanse Geneeskundige en Tandheelkundige Raad (hierna genoem die Raad) kon registreer en die registers wat hiervolgens gehou is, deel was van die aanvullende gesondheidsdienste kragtens Wet No. 13 van 1928, het verpligte registrasie vir persone wat die titel "sielkundige" (dit sluit bedryfsielkundige in) gebruik, eers met Wet 56 van 1974 ingetree (Van der Merwe, 1978). Dieselfde streng akademiese, praktiese en etiese standaarde wat van toepassing is op die mediese beroep het volgens hierdie Wet ook toepaslik geword op enige voornemende beoefenaar van sielkundige prosedures, sielkundige toetse of psigoterapie (Van der Merwe, 1979).

Hierdie Wet wat enersyds daarop gemik is om die sielkundige professie te "beskerm" deur die titel "sielkundige" te beperk tot diegene wat volgens hierdie Wet geregistreer is, is andersyds primêr opgestel om die publiek teen uitbuiting en wanpraktyke op die sielkundige terrein te beskerm.

Om hierdie doelstellings te bereik, het die Raad volgens artikel 15 van hierdie Wet 'n beroepsraad vir Sielkunde ingestel om 'n hoë peil van professionele onderrig en professionele gedrag by lede van die Sielkunde beroep te bevorder. Beheer oor opleiding en registrasie volgens hoofstuk II van die Wet en in besonder artikel 16 van die Wet, het tot gevolg dat die 
persoon of opvoedkundige inrigting wat opleiding aan voornemende professionele sielkundiges/bedryfsielkundiges wil verskaf, by die Raad om goedkeuring van sodanige opleiding aansoek moet doen en besonderhede aangaande daardie opleiding aan die Raad moet verstrek.

Aangesien Bedryfsielkunde " $n$ relatief korter professionele geskiedenis as sommige ander sielkundige groepe (byvoorbeeld Kliniese sielkunde) het, was daar aan die einde van 1974 slegs 36 persone wat in eersgenoemde kategorie onder die Wet geregistreer was. Dit het op daardie tydstip 14,4\% van alle geregistreerde sielkundiges uitgemaak. Tans (dit is 31 Desember 1978) is hierdie syfers onderskeidelik 171 en $20,7 \%$.

Ofskoon dit dus duidelik is dat die aantal geregistreerde bedryfsielkundiges numeries feitlik vyfvoudig toegeneem het, was die persentasie toename in verhouding tot die totale aantal geregistreerde sielkundiges relatief beskeie. Die algemene toename in geregistreerde bedryfsielkundiges bly nietemin 'n bemoedigende teken gedagtig aan die nuttige rol wat die professie in Suid-Afrika op arbeidsekonomiese gebied te vervul het.

\section{Professionele verenigings}

Daar bestaan twee verenigings vir sielkundiges (ook bedryfsielkundiges) in SuidAfrika, naamlik die Suid-Afrikaanse Sielkundige Vereniging (SASV) wat in 1949 gestig is en tans ' $\mathrm{n}$ ledetal van ongeveer 500 het en die Sielkundige Instituut van die Republiek van SuidAfrika (SIRSA) wat in 1962 gestig is met 'n huidige ledetal van ongeveer 450 (Van der Merwe, 1978).

Die Suid-Afrikaanse Sielkundige Vereniging laat veelrassige lidmaatskap toe en die vereniging is voorts lid van die Internasionale Unie van Wetenskaplike Sielkunde (International Union of Psychological Sciences, IUPS). Daarteenoor is SIRSA se lidmaatskap slegs tot blankes beperk* (Griesel, 1979; Van der Merwe, 1978).

Lede van SASV word op hoogte gehou van ontwikkeling in hul vakgebied deur middel van 'n nuusbrief "Psygram" en ook "n tydskrif "S.A. Joernaal vir Psigologie". Hierdie stukke word wêreldwyd versprei. SIRSA se mondstuk is 'n gereelde joernaal "Die S.A. Sielkundige" sowel as periodieke eenmalige publikasies. (Orpen, 1972; Raubenheimer, 1974; Van der Merwe, 1978). Beide verenigings is daarop ingestel om die akademiese sowel as die

\footnotetext{
* 'n Konstitusionele wysiging in 1979 maak lidmaatskap van nie-blankes moontlik.
} 
professionele belange van sielkundiges en bedryfsielkundiges en die vakgebied as geheel in Suid-Afrika te bevorder. Elke vereniging hou voorts 'n register wat voorsiening maak vir die registrasie van lede in kategorieë van die vakgebied soos kliniese sielkunde, opvoedkundige sielkunde, voorligtingsielkunde, pastorale sielkunde en bedryfsielkunde asook psigotegnici wat hoofsaaklik gemoeid is met sielkundige toetsing. Om as 'n bedryfsielkundige by enige van hierdie verenigings te registreer, moet ' $n$ individu ' $n$ meestersgraad in die sielkunde verwerf het en ten minste ' $\mathrm{n}$ jaar "goedgekeurde" praktiese opleiding, verkieslik in die handel en nywerheid ondergaan het (Orpen, 1972; Raubenheimer, 1974b).

Hierdie vereistes vir registrasie verskil op die oog af weinig, met die vereistes vir registrasie as 'n bedryfsielkundige volgens die Wet soos hierbo beskryf. Daar dien in hierdie verband gemeld te word dat hierdie twee verenigings in 1970 tot die besef gekom het dat daar onderlinge skakeling en beraadslaging sal moet plaasvind ten einde die professie te "organiseer" en het sodoende 'n groot rol gespeel in die skepping van statutêre professionele registrasie vir publieke beskerming. Dit het die aparte professionele raad vir sielkundiges (Die Beroepsraad vir Sielkunde) deur middel van Wet 56 van 1974 tot gevolg gehad (Van der Merwe, 1978).

Die SASV en SIRSA het tot en met 1978 onafhanklike jaarlikse kongresse gehou waar die verskillende kategorieë van sielkunde by wyse van onder andere die lewering van seminare aandag geniet het (Raubenheimer, 1974b). Pogings tot samewerking tussen die twee verenigings het egter verder momentum gekry met die stigting van 'n skakelkomitee en gedurende 1977 die uitbreiding van hierdie komitee tot 'n Verteenwoordigende Komitee van Sielkundige Verenigings. Hierdie komitee was dan ook grootliks daarvoor verantwoordelik dat daar op 5 September 1978 by die kongres-sentrum van die WNNR te Scientia in Pretoria 'n gesamentlike sielkundige kongres gehou is (Van der Merwe, 1978). 'n Verdere gesamentlike kongres het gedurende die week van 10 - 14 September 1979 in Potchefstroom plaasgevind (Griesel, 1979).

Aangesien daar 'n neiging in die Sielkunde-professie is om spesialiteitsgroepe te vorm, ontstaan daar voorts professionele verenigings vir hierdie spesialiteitsgroepe soos byvoorbeeld die Vereniging van Voorligting Sielkundiges en van Kliniese Sielkundiges (daar is nog nie ' $\mathrm{n}$ vereniging van bedryfsielkundiges nie).

Die Verteenwoordigende Komitee van Sielkundige Verenigings se doelstelling is om sake van gemeenskaplike belang namens SIRSA en SASV te hanteer. Wat 'n moontlike 
samesmelting van SIRSA en SASV betref, is geeneen van hierdie twee liggame bereid om op hierdie stadium hul identiteit prys te gee nie.

Uit die voorafgaande blyk dit dat die posisie van die bedryfsielkundige betreffende verteenwoordiging in een professionele vereniging tans nog baie onseker is. Die stigting van 'n oorkoepelende Sielkundige vereniging en daaropvolgende moontlike segmentasie, kan egter bedryfsielkundiges wat lid is van sodanige oorkoepelende vereniging noop om na die wenslikheid van 'n subvereniging vir hul professie (byvoorbeeld 'n vereniging vir bedryfsielkundiges) onder hierdie vereniging te kyk.

Vir diegene wat hul op die terrein van personeelbestuur bevind, bestaan daar 'n professionele liggaam naamlik die Instituut van Personeelbestuur van Suid-Afrika (IPBSA). Wat die verhouding tussen die professionele bedryfsielkundiges en hierdie vereniging betref, is die posisie egter tans nog baie onseker. Sommige akademiese instellings moedig nogtans studente in die Bedryfsielkunde aan om hul by die IPB aan te sluit (Augustyn et al., 1978).

Die professionele verenigings van 'n professie speel 'n prominente rol in die daarstelling van 'n etiese gedragskode vir sy lede. Dit bring ons by die volgende kriterium van 'n professie, naamlik:

\section{Professionele/etiese gedragskode (altruïstiese diens)}

Die Beroepsraad vir Sielkunde wat ingestel is kragtens artikel 15 van die Wet ten einde sorg te dra dat 'n hoë peil van professionele onderrig en professionele gedrag by die sielkunde beroep bevorder word, bepaal die etiese standaarde vir bedryfsielkundiges wat volgens hierdie Wet geregistreer is (Van der Merwe, 1979).

Hoofstuk III van hierdie Wet en in besonder artikel 37 van die Wet, spesifiseer dan ook die strawwe wat op sielkundiges (ook bedryfsielkundiges) sowel as intern-sielkundiges van toepassing is, indien hulle praktiseer terwyl hulle ongeregistreerd is.

Voorts behandel Hoofstuk IV en in besonder artikel 48 van hierdie Wet die tugbevoegdhede van die Geneeskundige en Tandheelkundige Raad (die Beroepsraad vir Sielkunde) wanneer klagtes van wangedrag, gepleeg deur lede van die Sielkunde beroep, ontvang word.

Waar die Beroepsraad daarop ingestel is om hoofsaaklik die publiek te beskerm sal die professionele vereniging, terwyl dit die handhawing van etiese norme onderskryf, hoofsaaklik optree om die belang van lede van die professie te bevorder (Van der Merwe, 1979). 
Laasgenoemde stel dan ook gewoonlik die etiese kode op waarby lede van die professie hul moet hou ten einde die goeie naam van die professie te beskerm ofskoon die bevordering van die geesteswelsyn van die mens as doelstelling in beide die etiese kodes van Suid-Afrika se sielkundige verenigings (SIRSA en SASV) baie prominent beklemtoon word.

Hierdie kodes is so opgestel dat die Sielkunde as en professie sowel as die menslike welvaart bevorder mits lede hul hierby hou (Orpen, 1972).

Raubenheimer et al. (1976) opper in hierdie verband die mening dat die huidige etiese kodes vir sielkundiges oorspronklik vir en deur klinici geformuleer is en dat die kodes dus vanuit ' $n$ bedryfsielkunde oogpunt gesien, soms onuitvoerbaar is.

Indien dit in gedagte gehou word dat die gesagsposisie wat spesialiteitskennis aan die professionalis bied ook ' $n$ vertrouensverhouding met die gemeenskap wat gedien word veronderstel, dan is dit belangrik dat die professionalis in die daarstelling van professionele norms ook krities kyk na die verhouding tussen hom en sy "werksveld" (Boshoff \& Hamblin, 1976).

Bedryfsielkundiges is hoofsaaklik werknemers van verskeie tipes organisasies en relatief min werk as outonome professionaliste. Hierdie organisasies kan ook hoofsaaklik as die "kopers" van bedryfsielkundige dienste oftewel die kliënte van die bedryfsielkundige beskou word (Boshoff \& Hamblin, 1976).

Dit is in die lig hiervan dat die kliniese/mediese model, dit wil sê die individuele professionalis teenoor die individuele kliëntmodel wat as grondslag vir bogemelde kodes gebruik is, soms onaanvaarbaar vir die professionele bedryfsielkundige is.

Gevolglik sal die verskillende hoedanighede waarin die bedryfsielkundige in die praktyk funksioneer (byvoorbeeld voltydse konsultant, gesalarieerde werknemer wat raadgewend tot bestuur optree of die akademiese konsultant wat periodieke konsultasiewerk doen, ensovoorts, in ag geneem moet word wanneer 'n etiese kode vir sielkundiges, wat bedryfsielkundiges insluit opgestel word (McGehee, 1964).

Die kliniese/mediese model van konsultasie oorbeklemtoon vanuit 'n bedryfsielkundige oogpunt die belange van die individu teenoor die van die kliëntorganisasie, maar aan die ander kant kan bedryfsielkunde ook nie as 'n vorm van "besigheid" bedryf word nie. Hieroor het McGehee (1964, p. 800), die volgende te sê: "Business and professional practice are not compatible, not only can they not occupy the same bed, they cannot even live in the same house". 
Dit blyk dus dat dit nodig geword het dat daar by wyse van 'n formele etiese kode eenstemmigheid verkry word rakende die morele verpligtinge en professionele standaarde van die bedryfsielkundige.

\section{Professionele vergoeding}

As lid van die sielkundige beroep/professie in Suid-Afrika, is die geldetarief wat 'n geregistreerde bedryfsielkundige vir sy dienste vra, onderworpe aan die bepalings van die Wet en in besonder artikels 53A en 54 van die Wet.

Vertoë rakende geldetariewe vir professionele dienste gelewer deur sielkundiges word gewoonlik deur 'n verteenwoordigende sielkundige vereniging of enige liggaam van persone wat na die oordeel van die Geneeskundige en Tandheelkundige Raad (Die Beroepsraad vir Sielkunde) verteenwoordigend van die persone wie se name op die register ten opsigte van die sielkunde beroep verskyn, tot die Raad gerig (Wet 56 van 1974 soos gewysig p. 810).

Dit is hieruit duidelik dat die professionele vereniging van ' $n$ besondere professie ' $n$ primêre rol speel ten einde geldetariewe te bepaal wat realisties en aanvaarbaar vir lede van die professionele groep sal wees. In die lig hiervan blyk een sterk sielkundige vereniging gevolglik wenslik te wees om die behoeftes en belange van die verskillende kategorieë van sielkundiges te koördineer ten einde 'n realistiese bepaling van tariewe daar te stel.

Wat die bepaling van geldetariewe van bedryfsielkundige dienste betref, behoort dit voorts in gedagte gehou te word dat die bedryfsielkundige meestal nie sy professie volgens die mediese/kliniese model (McGehee, 1964) bedryf nie. Die kliënte van bedryfsielkundiges is gewoonlik bedryfs- of ander vorme van organisasies (Boshoff \& Hamblin, 1976) en die lewering van 'n diens aan so 'n organisasie (byvoorbeeld die ontwikkeling van 'n toetsbattery vir 'n werknemersgroep van so 'n organisasie) behels verskeie prosesse en betrek verskeie individue waaraan spesifieke tye afgestaan moet word, ten einde die proses suksesvol te voltooi.

Die bedryfsielkundige wat as ' $\mathrm{n}$ gesalarieerde werknemer van 'n organisasie werk, is vir sy vergoeding afhanklik van die bestuur se siening van die waarde wat sy dienste vir die organisasie kan inhou (verwys Raubenheimer et al., 1976, oor die benutting van die bedryfsielkundige). Boshoff en Hamblin (1976, pp. 30-31) betrek in hierdie verband die gespesialiseerde opleiding van die bedryfsielkundige ter bevordering van die beeld van die bedryfsielkunde wanneer hulle 'n "aksieplan" voorstel gerig op: "creating a managerial awareness of the limits of amateur industrial psychologists". 
Dit blyk dus asof gespesialiseerde opleiding en kundigheid die grootste rol te speel het ter bevordering van die beeld van die bedryfsielkundige by die bestuur van organisasies en voortspruitend hieruit moontlik ook 'n billike vergoedingstruktuur vir die professionele bedryfsielkundige in diens van sodanige organisasies.

\section{GEVOLGTREKKINGS EN AANBEVELINGS}

\section{Gevolgtrekkings}

\section{Algemeen}

Wat die posisie van Bedryfsielkunde met betrekking tot die verskillende kriteria vir 'n professie betref, blyk dit asof die vakgebied/professie alreeds vir 'n aantal jare met 'n oorgangsfase tot ' $n$ volwaardige professie besig is. Dit is veral opvallend wanneer na die kriteria rakende professionele verenigings en 'n professionele kode gekyk word. Bedryfsielkunde het nog nie 'n professionele vereniging wat daadwerklik na sy besondere belange omsien nie en ook nie 'n professionele kode wat op sy besondere beroepsposisie van toepassing is nie.

Aan die ander kant beskik Bedryfsielkunde wel oor 'n deeglike liggaam van wetenskaplike kennis en bestaan daar volgens wetgewing reeds 'n vorm van professionele opleiding om die kundigheid van die geregistreerde bedryfsielkundige te verhoog. Hierdie wetgewing oefen ook beheer uit oor wangedrag aan die kant van die geregistreerde bedryfsielkundiges en "verbied" ongeregistreerde persone om as sielkundiges te praktiseer. Die bedryfsielkundige professie is gevolglik statutêr goed georganiseer.

\section{Spesifiek}

- Wat die opleiding van die voornemende professionele bedryfsielkundige betref, dui die voorafgaande daarop dat ' $n$ gerigte kursus bestaande uit akademiese sowel as praktiese opleiding deur akademici in samewerking met praktici, uitgewerk behoort te word om die nodige professionele liggaam van kennis vir die praktyk te voorsien. Aangesien bedryfsielkunde as 'n onafhanklike toegepaste wetenskapsdissipline in eie reg beskou kan word, is dit noodsaaklik dat voornemende professionele bedryfsielkundiges eenvormig binne ' $\mathrm{n}$ spesifieke leergang opgelei word waarin daar in 'n mindere of meerdere mate onderskeidelik met die suiwer sielkunde, die sosiale wetenskappe en die ekonomiese wetenskappe in aanraking gekom sal word. 
- Ofskoon erkenning verleen wil word aan die Departement van Gesondheid vir wat gedoen is ten opsigte van die statutêre erkenning van Bedryfsielkunde as 'n professie, word daar tot die gevolgtrekking gekom dat daar in hierdie verband nie "ver genoeg" gegaan is nie. Die Sielkunde (ook Bedryfsielkunde) word volgens die Wet hoofsaaklik as 'n aanvullende professie tot die mediese professie gesien en terwyl Bedryfsielkunde 'n groot verwantskap met die ekonomiese wetenskappe het en op die arbeidsekonomiese terrein (byvoorbeeld bedryfsgeestesgesondheid) sy grootste bydrae maak, kom die vraag onwillekeurig op of 'n ondersoek rakende die posisie van die geregistreerde bedryfsielkundige volgens die Wet, met verwysing na sy funksies in die beroeps- en bedryfslewe, nie wenslik geword het ten einde groter erkenning aan die besondere beroepsposisie van die bedryfsielkundige te verleen nie.

Dit skyn asof Bedryfsielkunde as vakgebied afgegrens moet word en dat alle persone wat binne hierdie "veld" werk (byvoorbeeld personeelsielkundiges, verkoopsielkundiges, ensovoorts). by 'n vorm van wetlike registrasie betrek moet word. Dit kan moontlik gedoen word nadat 'n aparte Sielkundige Raad, geskep deur middel van gesondheidswetgewing met sub-rade vir die spesialiteitsrigtings in die Sielkunde (soos Bedryfsielkunde), in die lewe geroep is om Sielkunde los te maak van die "aanvullende professie" beeld wat dit tans het.

- Wat 'n professionele vereniging vir bedryfsielkundiges betref, lyk dit asof dit raadsaam sal wees om te wag tot na die stigting van die sambreelvereniging in die Sielkunde wat tans deur die Verteenwoordigende Komitee van Sielkundige Verenigings in die vooruitsig gestel word.

- $\quad$ Met betrekking tot die etiese gedragswyse wat bedryfsielkundiges behoort te volg, lyk dit asof daar besondere aandag aan die besondere beroepsposisie van die bedryfsielkundige geskenk sal moet word, veral gedagtig aan die kliniese/mediese model wat in die huidige etiese kodes van sielkundige verenigings geïmpliseer word.

- $\quad$ Uit die voorafgaande word die indruk gekry dat die vergoedingspeil van die professionele bedryfsielkundige in 'n groot mate afhanklik is van die "waarde" wat sy dienste vir die organisasie (in besonder die bestuur van die organisasie), by wie hy in diens is, inhou.

Voorts kan 'n "sterk" professionele vereniging vir die bedryfsielkundige in hierdie verband van besondere waarde wees ten opsigte van die vasstelling van moontlike 
minimum aanvangsalarisse, die betaling van moontlike professionele toelae en/of die bedinging van minimum fooie by die Beroepsraad vir Sielkunde wanneer bedryfsielkundedienste op 'n konsultasiebasis aangebied word.

\section{Aanbevelings vir verdere ondersoeke/navorsing}

Uit die voorafgaande gevolgtrekkings blyk dit noodsaaklik dat daar by wyse van 'n ondersoek of navorsing aan die volgende aspekte aandag geskenk word.

- $\quad$ Om aan die professionele bedryfsielkundige die "regte" liggaam van kennis te voorsien, behoort eenvormigheid verkry te word rakende die opleiding van bedryfsielkundiges met spesifieke verwysing na die universiteite waar bedryfsielkunde as vak doseer word. Die kwessie van opleiding binne 'n spesifieke leergang kan ook in so 'n ondersoek aandag geniet. Die primêre doelstelling van so 'n ondersoek word geag 'n beter omlynde betekenis aan die term "bedryfsielkundige" te gee, sodat die kliënte van die bedryfsielkundige 'n realistiese verwagting van laasgenoemde se professionele dienste sal koester.

- $\quad$ Ten opsigte van die statutêre organisering van Bedryfsielkunde word 'n ondersoek na die moontlikheid van 'n onafhanklike beroepsraad vir Sielkunde en nie as onderdeel van die Geneeskundige en Tandheelkundige Raad nie, 'n dringende noodsaaklikheid geag indien dié professie hom enigsins sou wou losmaak van die "aanvullende professie" beeld wat dit tans geniet. In so 'n ondersoek kan die moontlikheid van sub-rade vir die verskillende spesialiteitsrigtings in die Sielkunde ook moontlik ondersoek word.

- $\quad$ Ten einde die Sielkunde professie en die Bedryfsielkunde in samehang hiermee die professionele gesag te gee wat noodsaaklik is vir die ontwikkeling daarvan, word 'n dringende ondersoek na die stigting van een "sterk" sielkundige vereniging met moontlik (na gelang van die behoefte), sub-verenigings geaffilieer aan hierdie moedervereniging, as noodsaaklik geag. In die proses behoort die SASV en SIRSA en wanneer daar aan 'n aparte vereniging vir bedryfsielkundiges aandag geskenk word, ook die IPB (SA) betrek te word ten einde die kwessie van Sielkundige/bedryfsielkundige verenigings in Suid-Afrika volledig te konsolideer.

As agtergrond vir so 'n ondersoek kan aan 'n meningsopname onder bedryfsielkundiges in Suid-Afrika, geïnisieer deur 'n akademiese instelling en gevolg deur 'n kongres/ simposium, gedink word. 
- $\quad$ Met verwysing na die etiese gedragswyse en besondere beroepsposisie van bedryfsielkundiges (hulle is meestal in diens van organisasies) kan die moontlikheid van 'n etiese kode vir bedryfsielkundiges as sulks ondersoek word.

Indien regverdiging vir ' $\mathrm{n}$ afsonderlike etiese kode vir bedryfsielkundiges gevind sou word, sal ' $n$ bespreking hiervan op ' $n$ kongres/simposium deur bedryfsielkundiges uit die akademie en die praktyk noodwendig moet volg. In gemelde ondersoek en die bespreking wat hierop sou volg, behoort die rol van organisasiedoelstellings, die belange van die groter werksgroep(e) en die individu in die organisasie by die lewering van bedryfsielkundige dienste met mekaar in perspektief gebring te word.

\section{OPSOMMING}

Bedryfsielkunde, as relatief jong maar snelgroeiende wetenskap, word aan die hand van ses kriteria vir 'n professie evalueer. Resultate in hierdie verband dui in die algemeen daarop dat die vakgebied alreeds vir 'n aantal jare in 'n oorgangsfase tot ' $n$ volwaardige professie is en dat daar in hierdie proses reeds ver op die professionele kontinuum gevorder is. Verdere onder-soeke ten opsigte van professionele opleiding, die statutêre organisering van Bedryfsielkunde asook 'n professionele kode en vereniging vir die Bedryfsielkunde word bepleit ten einde die professionele posisie van die vakgebied volledig te konsolideer.

\section{VERWYSINGS}

Anoniem. The Professions, Careers/Loopbane, Handbook on Juvenile employment in the Cape Town area. Cape Division Juvenile Affairs Board, 1941.

Anoniem. Management Consultants, Management, 1978, April/May, 43-61.

Argyris, C. \& Schön, D.A. Theory in practice: Increasing Professional Effectiveness. London: Jossey Bass Publishers, 1975.

Augustyn, J.C.D. Die vrae wat ons altyd wou gevra het. Perspektiewe in die Bedryfsielkunde, 1977, 3(4), 1-7.

Augustyn, J.C.D., De Villiers, W.S., Raubenheimer, I. van W. \& Van Biljon, I.J. Die Opleiding van bedryfsielkundiges aan die Universiteit van Stellenbosch. Perspektiewe in die Bedryfsielkunde, 1978, 4(3), 27-35.

Beach, D.S. Personnel: The Management of People at Work. New York: MacMillan, 1970.

Bent, R.J. A professional issue - The psychologist supervised by medical doctors. Professional Psychology, 1972, 3, 351-356.

Boshoff, A.B. \& Hamblin, E. Academic and professional requirements, ethical considerations and skills in the application of industrial psychological knowledge. Perspektiewe in die Bedryfsielkunde, 1976, 2(5), 17-33.

Botha, W. Die opleiding van bedryfsielkundiges aan die Universiteit van Fort Hare. Perspektiewe in die Bedryfsielkunde, 1977, 3(4),63-71.

Brayfield, A.H. Psychology as a profession. American Psychologist, 1968, 23, 195-200. 
Carroll, C.E. The Professionalization of Education for Librarianship 1940- 1960. New Jersey: The Scarecrow Press, 1970.

Chapman, B. The Profession of Government: The Public Service in Europe. London: Allen and Unwin, 1963.

Duckat, W. A Guide to Professional Careers. New York: Julian Messner, 1970.

Dunnette, M.D. Handbook of Industrial and Organizational Psychology. Chicago: Rand McNally, 1976.

Durkheim, E. Professional Ethics and Civic Morals. London: MacMillan, 1972.

Elliott, P.R.C. The Sociology of the Professions. London: MacMillan, 1972.

Freidson, E. Profession of Medicine: A Study of the Sociology of Applied Knowledge. New York: Dodd Meadt Publishers, 1971.

Griesel, R.D. Instituut van gedragswetenskappe UNISA, mededelings aan die Ministerie van Nywerheidswese en van Handel en Verbruikersake. September, Oktober en November, 1979.

Hattingh, J.M. Kliniese Sielkunde, professionalisme en 'n eie identiteit. Die Suid-Afrikaanse Sielkundige, 1966, 53, 1-8.

Hornby, A.S., Gatenby, E.V. \& Wakefield, H. The Advanced Learner's Dictionary of Current English. London: Oxford University Press, 1963.

Kamfer, L,. Die opleiding van bedryfsielkundiges aan die Universiteit van Port Elizabeth. Perspektiewe in die Bedryfsielkunde, 1977, 3(3), 29-36.

Kerlinger, F.N. Foundations of Behavioral Research. New York: Holt Rinehart and Winston, 1973.

Kerr, S. \& Von Glinow, M.A. Issues in the study of "Professionals" in organizations: the case of scientists and engineers. Organizational Behaviour and Human Performance, 1977, $18,329-345$.

Korman, M. National conference on levels and patterns of professional training in psychology - The major themes. American Psychologist, 1974, 29, 441-449.

Langenhoven, H.P. Die menslike faktor in die bedryf. Professorale intreerede, Die Universiteit van die Oranje Vrystaat, Bloemfontein, 5 Maart, 1969.

Langenhoven, H.P. Die opleiding van bedryfsielkundiges aan die Universiteit van die Oranje Vrystaat. Perspektiewe in die Bedryfsielkunde, 1977, 3(1), 37-44.

MacFarlane, J.W. Ethical standards and public responsibility, discussion on ethics. American Psychologist, 1952, 7, 435-437.

MacKinney, A.C. The masters degree in industrial psychology. American Psychologist, 1968, 23, 342-356.

McGehee, W. And Esau was a hairy man. American Psychologist, 1964, 19, 799-804.

Muchinsky, P.M. Graduate training in industrial psychology - one more time. Professional Psychology, 1973, 4, 268-295.

Orpen, C. Industrial psychology in South Africa. Bedryfsleiding, 1972, November, 12-15.

Peterson, D.R. Is psychology a profession? American Psychologist. 1976, 31, 572-580.

Raubenheimer, I. van W. Enkele gedagtes oor die opleiding van bedryfsielkundiges in SuidAfrika. Monografieë van die SIRSA, 1974, 182(a).

Raubenheimer, I. van W. Industrial psychology in South Africa. Psychologica Africana, 1974, 15, 111-118(b).

Raubenheimer, I. van W., Calitz, C.J., De Villiers, W.S. \& Augustyn, J.C.D. Die opleiding van bedryfsielkundiges in Suid-Afrika. Perspektiewe in die Bedryfsielkunde, 1976, 2(3), 1-27.

Schoeman, C.F. Die opleiding van bedryfsielkundiges aan die Potchefstroomse Universiteit vir Christelike Hoër Onderwys. Perspektiewe in die Bedryfsielkunde, 1978, 4(1), 55-59. 
Swiegers, D.J. Die bedryfstoepassing van die kundigheid van die Bedryfsielkundige. Die Suid-Afrikaanse Sielkundige, 1970, 99, 1-9.

Theodore, A. The Professional Woman. Cambridge, Massachusetts: Schenkman Publishing, 1971.

Towle, C. The Learner in Education for the Professions (as seen in Education for Social Work). Chicago, Illinois: University of Chicago Press, 1954.

Uhrbrock, R.S. Internships versus field training for industrial psychologists. American Psychologist, 1955, 10, 535-538.

Van der Merwe, P.R. Uitvoerende Direkteur van die Aptekersvereniging van Suid-Afrika, persoonlike menings, "verslag". S.A.T.V., Augustus, 1979.

Van der Mewe, S.W. Openingstoespraak deur sy edele Dr. S.W. van der Merwe, Minister van Gesondheid by die geleentheid van die gesamentlike sielkundige kongres, Pretoria, 5 September, 1978. (Uitgereik deur die Buro vir Nasionale en Internasionale kommunikasie op versoek van die Ministerie van Gesondheid, Pretoria, 2 Augustus, 1978).

Van der Merwe, S.W. Openingsrede deur sy edele Dr. S.W. Van der Merwe, Minister van Gesondheid by geleentheid van die jaarlikse kongres van die vereniging van kliniese sielkundiges, Stellenbosch, 26 April 1979. (Uitgereik deur die inligtingsdiens van SuidAfrika op versoek van die Minister van Gesondheid, Kaapstad, 26 April, 1979).

Vlok, A. Die opleiding van bedryfsielkundiges aan die Universiteit van Suid-Afrika. Perspektiewe in die Bedryfsielkunde, 1977, 3(2), 15-21.

Vollmer, H.M. \& Mills, D.L. Professionalization. Englewood Cliffs, New Jersey: PrenticeHall, 1966.

Wilson, R.F. Internships in industrial psychology. American Psychologist, American Psychologist, 1956, 11, 243-246.

Wolfle, D. Legal control of psychological practice. American Psychologist, 1950, 5(12), 651655. 